\title{
Model pemrosesan informasi Gregory Bateson dalam pendekatan sibernetis
}

\author{
Subekti W. Priyadharma \\ Universitas Padjadjaran, Bandung, Indonesia
}

\begin{abstract}
ABSTRAK
Pendekatan sibernetis Gregory Bateson belum banyak diaplikasikan dan dikembangkan dalam kajian-kajian komunikasi di Indonesia. Oleh karena itu, artikel yang berfokus untuk mengangkat pendekatan sibernetis semacam ini ke permukaan menjadi sangat penting. Melalui studi literatur, artikel ini mengulas model pemrosesan informasi dari Gregory Bateson dengan mengambil pendekatan sibernetis yang didasarkan pada teori sistem umum dengan premis-premis sebab-akibatnya. Teori sistem dan perspektif sibernetis seringkali digunakan dalam analisis fenomena komunikasi dan informasi untuk melihat sejauh mana perubahan dalam komponen-komponen sebuah sistem memiliki dampak terhadap sistem secara keseluruhan. Lebih jauh, dalam artikel ini juga diulas mengenai kaitan antara prinsip-prinsip dalam pendekatan sibernetis dengan beberapa teori populer seperti interaksionisme simbolis, fenomenologi sosial, dan teori kekacauan. Relasi sibernetika dan interaksionisme simbolis terletak pada pembahasan tentang konteks dan konsep redundansi, yang dalam interaksionisme simbolis disebut sebagai cadangan pengetahuan atau cadangan makna. Pendekatan sibernetis bersesuaian dengan fenomenologi ketika fenomenologi menguraikan pola tindakan manusia yang dijelaskan melalui konsep tipifikasi dan appresentasi. Resiprositas, yang merupakan salah satu konsep penting dalam fenomenologi sosial, juga memiliki irisan yang dalam dengan mekanisme umpan balik dalam sibernetika. Akhirnya, prinsip-prinsip umum pendekatan sibernetis juga ditemukan dalam teori kekacauan atau chaos theory, dimana keduanya menganggap bahwa fenomena komunikasi dan/atau fenomena alam merupakan bagian dari sistem yang lebih besar yang saling terhubung satu sama lain. Baik sibernetika maupun teori kekacauan, keduanya menganut mekanisme sebab-akibat untuk menjelaskan bagaimana proses komunikasi atau semesta secara umum bekerja.
\end{abstract}

Kata-kata Kunci: sibernetis; teori sistem; interaksionisme simbolis; fenomenologi; teori kekacauan

\section{Gregory Bateson's information processing model in cybernetic approach}

\section{ABSTRACT}

Gregory Bateson's cybernetic approach has not been widely applied and developed in communication studies in Indonesia. Therefore, an article that focuses on bringing such approach to the surface becomes very important. Through a literature study, this article reviews Bateson's information processing model by taking cybernetic explanation based on the general system theory with its causal-effect premise. System theory and cybernetic explanation are often used in the analysis of communication and information issues to see the extent of changes in the component of a system has an impact on the system as a whole. Furthermore, this article also reviews the link between principles in cybernetic approach and some popular theories such as symbolic interactionism, social phenomenology, and chaos theory. The relation of cybernetics and symbolic interactionism lies in the discussion of context and the concept of redundancy, which in symbolic interactionism is called the reserve of knowledge or the reserve of meaning. Cybernetic explanation corresponds to phenomenology when the latter describes the patterns of human action that are explained through the concepts of typification and appresentation. Reciprocity, which is one of the important concepts in social phenomenology, also disjoints with the feedback mechanisms in cybernetics. Finally, the general principles of cybernetics are also found in chaos theory, both of which assume that communication and/or natural phenomena are part of a larger system that is interconnected with one another. Both cybernetics and chaos theory adhere to causal-effect mechanisms to explain how the communication process or generally the universe works.

Keywords: cybernetic; system theory; symbolic interactionism; phenomenology; chaos theory

Korespondensi: Subekti Wirabhuana Priyadharma, M.A. Universitas Padjadjaran. Jalan Raya Bandung Sumedang KM.21 Jatinangor 45363.Email: subekti.w.priyadharma@unpad.ac.id 


\section{PENDAHULUAN}

Dunia atau alam semesta kita dapat dilihat sebagai sebuah sistem kehidupan yang besar di mana bagian-bagiannya dapat diperlakukan sebagai sistem-sistem pemrosesan yang lebih kecil yang di dalamnya juga memiliki elemenelemen yang lebih kecil yang berfungsi sebagai subsistem dan demikian selanjutnya. Semua sistem ini saling berhubungan sehingga perubahan kecil dalam suatu sistem atau bagian dari suatu sistem dapat memengaruhi komponen sistem lainnya atau sistem tersebut secara keseluruhan. Dapat dikatakan bahwa suatu sistem beroperasi seperti kumpulan gerigi di dalam sebuah mesin yang bekerja terus menerus untuk menjaga kinerja mesin tersebut sehingga dapat terus menghasilkan sesuatu.

Proses yang sama juga dapat ditemukan dalam kehidupan sosial masyarakat kita. Orang berinteraksi satu sama lain dan mereka saling memengaruhi. Mereka secara konstan bekerja dan membuat berbagai produk, seperti barang, layanan, atau ide, sehingga mereka dapat bertahan hidup dengan cara seperti ini. Dengan kata lain, untuk bertahan hidup, manusia, yang di sini dipandang sebagai suatu sistem tersendiri atau kumpulan beberapa subsistemsubsistem tubuh yang kecil, harus membuka diri mereka untuk menerima rangsangan eksternal (input), baik itu informasi, energi atau materi, yang kemudian diproses oleh sistem (throughput), dan menghasilkan produk (output) tertentu. Produk buatan ini kemudian menjadi input ke sistem yang lain (orang lain, hewan, alam, institusi, negara, dll.) proses yang sama kemudian berulang dan membentuk sebuah jaringan sistem kehidupan yang besar dari waktu ke waktu. Jadi kita saat ini tengah berada dalam sebuah proses atau dalam sebuah sistem yang sedang berjalan. Di sini kita dapat melihat bahwa mekanisme sistem semacam itu bereaksi terhadap rangsangan yang tidak linier, tetapi seperti rantai sebab akibat yang berfungsi melalui umpan balik yang dinamis karena memungkinkan sistem tersebut untuk memperkirakan dan beradaptasi dengan perubahan eksternal.

Menurut Bertalanffy, seorang ahli biologi yang memberikan pemaparan mengenai teori sistem dalam bukunya General System Theory, untuk memahami bagaimana sebuah sistem beroperasi, kita tidak seharusnya mereduksi sistem tersebut ke tiap-tiap bagiannya, tetapi penting untuk mengamati sistem tersebut sebagai sebuah kesatuan (Bertalanffy, 1998). Kita harus memperhatikan dengan baik hubungan antara unsur-unsur sistem dan antara sistem-sistem yang lebih kecil yang kesemuanya membentuk sistem yang lebih besar. Jika kita ingin menerapkan teori sistem dalam konteks kehidupan sosial kita, maka penting juga 
bahwa hubungan antara manusia, manusia dan lingkungannya, manusia dan institusi sosial, budaya, dll., yaitu antara manusia dan elemen masyarakat lainnya, dijadikan fokus perhatian dalam analisis kerja kita. Dengan begitu kita akan memahami dengan lebih baik bagaimana dunia sosial ini bekerja.

Melalui studi literatur, artikel ini membahas teori-teori yang secara konseptual memiliki kaitan yang erat dengan pendekatan sibernetis. Teori-teori tersebut menjelaskan bagaimana manusia dapat saling memahami dan bagaimana mereka memahami lingkungan sosialnya. Tulisan ini juga berkaitan dengan gagasan tentang bagaimana interaksi antara unsur-unsur masyarakat memainkan peran penting dalam kelangsungan hidup manusia, budaya, dan masyarakat. Kita kemudian akan melihat melalui teori-teori yang akan dijelaskan bahwa ada semacam keteraturan atau pola yang mengendalikan cara kerja dunia kehidupan. Fenomena keteraturan dan organisasi sistem ini sedang bekerja. Karya ini berfokus pada beberapa pendekatan komunikasi yang membahas tentang perilaku dan interaksi manusia, seperti Interaksionisme Simbolis (Blumer, 1973; Mead, 1968), beberapa konsep fenomenologi sosial (Schütz, 1993) dan pendekatan sibernetis (Bateson, 1983). Pendekatan sibernetis juga akan disandingkan dengan teori kekacauan karena ada beberapa prinsip serupa yang dikaitkan kepada kedua teori/pendekatan tersebut. Teori-teori tersebut lalu disusun dalam sebuah platform untuk mencoba menggambarkan relasi-relasinya, sehingga kita dapat memandang fenomena komunikasi manusia secara keseluruhan, tidak hanya berfokus pada bagian-bagiannya, seperti yang disarankan oleh teori sistem-nya Bertalanffy.

Dalam bagian selanjutnya akan diuraikan metode penelitian yang dilanjutkan dengan pembahasan tentang Model Pemrosesan Informasi dari Gregory Bateson. Model tersebut memuat pendekatan sibernetis yang kemudian dibandingkan dengan pendekatan-pendekatan komunikasi lainnya.

\section{METODE PENELITIAN}

Metode yang digunakan dalam penelitian ini adalah studi literatur tentang teori-teori yang berkenaan dengan pendekatan sibernetis. Oleh karena itu, artikel ini tidak mengulas hasil penelitian yang menggunakan teoriteori dimaksud. Studi literatur mendalam tentang teori pernah dilakukan oleh Mirawati dan Karimah untuk jurnal ini ketika mereka membahas Chinese Harmony Communication Theory (Mirawati \& Karimah, 2018). Sementara itu dalam artikel ini, penulis mengkaji secara komprehensif terlebih dahulu model 
pemrosesan informasi dari Bateson dari sumber pertama, yaitu yang dimuat dalam publikasipublikasinya yang berbahasa Jerman dengan judul Ökologie des Geistes (Bateson, 1983) dan Geist und Natur (Bateson, 1984). Selanjutnya, penulis mengkaji tulisan-tulisan mengenai sibernetika Bateson dari sumber sekunder (Bale, 1995) dan mengenai sibernetika secara umum (Wiener, 1948). Beberapa prinsip sibernetika penulis dapatkan juga dari publikasi yang berjudul Die Entdeckung der kommunikativen Welt (Giesecke, 2007). Teori sistem umum, yang merupakan landasan bagi sibernetika, didapatkan dari Bertalanffy (Bertalanffy, 1998) melalui General System Theory.

Kajian-kajian mengenai interasionisme simbolik penulis dapatkan baik itu dari sumber primer, yaitu dari Mead (Mead, 1968) dan Blumer (Blumer, 1973), maupun dari sumber sekunder (Burkart, 1998). Selanjutnya, berbagai penjelasan mengenai fenomenologi dapat ditemukan dalam tulisan Alfred Schütz (Schütz, 1993): Der sinnhafte Aufbau der sozialen Welt, Gattungsanalyse (Knoblauch \& Luckmann, 2000), dan Soziologischen Kommunikationstheorien (Schützeichel, 2004).

Terakhir, penulis melakukan kajian literatur untuk mencari relasi antara teori kekacauan dengan penjelasan sibernetis. Uraian mengenai teori kekacauan, yang jarang dikaitkan dengan fenomena komunikasi, penulis dapatkan dari banyak literatur (Loistl \& Betz, 1996), (Rath, n.d.), (Scheidegger, 1997).

\section{HASIL DAN PEMBAHASAN}

Pendekatan sibenetis diturunkan khususnya dari teori sistem Bertalanffy (Bertalanffy, 1998) dan teori komunikasi matematis (Shannon \& Weaver, 1964). Namun, istilah 'sibernetis'sendiri ditelurkan oleh Norbert Wiener (Wiener, 1948) sesaat setelah Perang Dunia II berakhir. Istilah ini mengacu pada "the entire field of control and communication theory, whether in the machine or in the animal" (Wiener, 1948). Jadi menurut Wiener, perspektif ini memandang baik hewan maupun mesin secara sistematis tidak memiliki perbedaan. Selanjutnya, pendekatan sibernetis berkaitan dengan masalah komunikasi, yaitu sistem pikiran, sistem komunikasi, sistem sosial dan ekosistem. Sebagai sebuah sistem yang terorganisir, berikut merupakan definisi yang diberikan oleh Bale (Bale, 1995):

The system [...] is less a "thing" than a pattern of organization. Systems are comprised of a unified pattern of events, and their existence, as well as their character are derived more from the nature of their organization, than from the nature of their components. As such, a system consists of a dynamic flow of interactions that cannot themselves be quantified, weighed or measured.

Pola peristiwa-peristiwa dalam suatu sistem merupakan hal yang penting untuk mempertahankan keberlangsungan sistem 
itu. Kemampuan sebuah sistem atau sebuah organisme untuk bertahan hidup ditentukan oleh apa yang disebut Bertalanffy (Bertalanffy, 1998) sebagai steady state atau flux-balance. Selain itu, sistem-sistem seperti itu (misalnya sistem biologis, neurologis, psikologis, atau sosial) dapat dikenali melalui cirinya yang terbuka. Terkait keterbukaan sistem ini, Bale mengungkapkan penjelasan sebagai berikut:

They organize and sustain themselves by exchanging matter, energy and information with their environment. Moreover, it is precisely the processes involved in these exchanges that constitute the life and continuity of such living systems. For although a living system may replicate itself, no single component of the system is permanent [...] its components are constantly altered by metabolic events (Bale, 1995).

Menurut definisi di atas, dapat dikatakan, sebuah organisme selalu berada dalam suatu keadaan yang dinamis dan stabil (bukan statis), yaitu dalam suatu proses yang terus-menerus berlangsung. Ketidakmampuan suatu sistem atau organisme untuk beradaptasi dengan keadaan yang dinamis dan stabil ini akan memperlemah kesempatannya untuk bertahan hidup. Laszlo menyatakan kemampuan ini dinamakan cybernetic stability atau stabilitas sibernetis (Laszlo, 1973). Bateson bahkan menyoroti mekanisme sistem untuk mempertahankan status quo (Bateson, 1983). Dia kemudian menjelaskan bahwa sebuah sistem mencoba untuk menjaga eksistensinya secara konstan "dengan mengoreksi perubahan atau mengubah dirinya sendiri untuk beradaptasi dengan perubahan tersebut atau dengan menginternalisasi perubahan konstan tersebut ke dalam eksistensinya sendiri“ (Bateson, 1984). Pendekatan sibernetis dapat dibuktikan dengan prinsip penjelasan negatif atau reductio ad absurdum yang berasal dari ekspresi bahasa Latin. Dalam reductio ad absurdum, sebuah pernyataan dibantah dengan menunjukkan bahwa ada konsekuensi kontradiktif atau absurditas yang keluar dari pernyataan tersebut.

Dengan menjelaskan suatu peristiwa dengan penjelasan negatif, Bateson mengajukan pertanyaan "apa kemungkinan alternatif yang akan terjadi, dan kemudian bertanya (lebih lanjut) mengapa banyak dari alternatif-alternatif tersebut tidak terwujud, sehingga peristiwa tertentu adalah salah satu dari sedikit yang benarbenar terjadi.“ Bateson melanjutkan dengan contoh penjelasan negatif: "Contoh klasik dari penjelasan ini adalah teori evolusi tentang seleksi alam (Bateson, 1983). Menurut teori ini, organisme yang tidak dapat bertahan hidup baik dari segi fisiologi ataupun lingkungan, ia tidak akan hidup maupun bereproduksi. Karena itu evolusi selalu mengikuti prinsip kemampuan bertahan hidup.“(Bateson, 1983)

Namun, untuk menjaga kondisi yang seimbang, yaitu untuk menjaga keberlangsungan 
hidup, suatu sistem harus mengikuti prinsip pembatasan (Bateson, 1983). Prinsip ini berarti bahwa suatu sistem atau organisme biasanya akan mencoba membatasi diri pada beberapa bagian atau faktor sehingga dapat terus beroperasi atau hidup. Dengan kata lain, sistem tersebut mengoptimalkan faktor-faktor yang memberi mereka peluang lebih besar untuk beradaptasi dengan perubahan dan pada saat yang sama menghilangkan faktor-faktor yang kurang signifikan terhadap adaptasi ini. Menurut definisi Bateson, pembatasan dapat dipahami "sebagai faktor-faktor [...] yang menentukan ketidaksetaraan probabilitas $[\ldots]^{\text {“ }}$ (Bateson, 1983).

Misalnya, pilihan rute saat berkendara ke tujuan tertentu 'dibatasi' oleh banyak faktor. Kita berada di persimpangan jalan dan tidak tahu ke arah mana kami harus terus berkendara. Kita memiliki beberapa opsi untuk dipilih, sehingga kita dapat mencapai tujuan. Kita dapat mengumpulkan informasi dengan bertanya kepada seseorang di jalan, melihat peta, atau sekarang dengan menggunakan GPS (Global Positioning System). Konsekuensinya, apa yang akan kita lakukan hanyalah memperhatikan dan mengikuti informasi yang diberikan oleh seseorang di jalan yang kita tanya, informasi dari peta, atau dari GPS, dengan kata lain, kita membatasi perhatian kita pada informasi yang kita pilih. Dengan asumsi bahwa informasi tersebut benar, kita akan tiba di tujuan, jika tidak, proses yang sama harus berjalan lagi dan kita akan beradaptasi dengan perubahan tersebut, membatasi lagi pada informasi baru, dan selanjutnya. "Untuk orang yang berusaha mencapai [...] (tujuannya) semua adalah petunjuk, yaitu sumber informasi yang akan membimbingnya dalam (mengambil keputusan untuk) pemilihan. Untuk seorang pengamat sibernetis, semua itu adalah pembatasan" (Bateson, 1983). Semua proses ini adalah upaya untuk mempertahankan keseimbangan aliran. Karena itu, sebuah sistem dilihat dari hal kemampuanya mengatur diri sendiri untuk menangani atau merespon terhadap perubahan.

Pembatasan merujuk pada dua kategori lain yang juga menempati posisi sentral dalam pendekatan sibernetis. Kedua kategori tersebut adalah karakter "umpan balik" dan "redundan" dari sebuah sistem.

Umpan Balik. Bateson menyatakan peristiwa dan objek, yang ia ungkapkan sebagai data yang "telanjang", bukanlah subjek dari sibernetis. Menurutnya, data hanyalah informasi yang ditransmisikan yang sebelumnya diubah dan ditangkap oleh kesadaran manusia atau beragam instrumen mereka dengan cara mempersepsi dan mengomunikasikan informasi tersebut (Bateson, 1983). Itulah sebabnya apa yang menjadi pokok diskusi kita di sini berkaitan dengan hal dengan proses 
transfer informasi dalam suatu sistem, baik itu makhluk hidup, mesin atau masyarakat. Sistem direpresentasikan sebagai sirkuit yang tertutup atau terbuka. Sebagai sistem yang tertutup, "jelas bahwa peristiwa di suatu titik yang manapun dalam sirkuit akan memberikan pengaruh pada semua posisi di dalam sirkuit pada tahap selanjutnya". Pada sisi yang lain, "sistem seperti itu selalu bersifat terbuka: (a) dalam pengertian bahwa sebuah sistem menarik energinya dari sumber eksternal dan biasanya melepaskan energi ke luar dalam bentuk panas; dan (b) dalam arti bahwa peristiwaperistiwa dalam sistem dapat dipengaruhi dari luar atau sebaliknya memengaruhi peristiwaperistiwa eksternal" (Bateson, 1983). Seperti halnya Bateson yang mengilustrasikan proses ini dengan mesin penggerak roda, Bale juga memberikan contoh sistem umpan balik sebagai berikut:

An accessible example of the cybernetic model is the thermostatically controlled heating system. The entire unit, weatherhouse-heater-thermostat-homeowner, is here understood as a system of communication. The thermostat contains a thermometer (a receptor or a sort of sense organ), which responds to messages or transforms of difference (e.g., information) between a specified ideal temperature and actual changes in room temperature. Note that it is the homeowner who specifies, sets or encodes, the thermostat's ideal temperature. The thermostat will respond to its own codification of the change--not to a physical energy transfer- -and will signal the heater to turn off or on, thereby equilibrating to conserve the system 's ideal temperature (Bale, 1995).
Bateson menunjukkan bahwa sistem seperti itu bersifat sirkuler (tertutup). Artinya, “[...] efek dari sebuah peristiwa (dapat) ditransmisikan pada setiap titik di dalam sistem untuk membangkitkan perubahan kembali pada titik awal (dimana peristiwa itu terjadi)" (Bateson, 1984). Dalam kasus sistem termostat atau sistem pendingin ruangan (AC) otomatis, kita bisa membayangkan tindakan seorang pemilik rumah sebagai titik awal. Di awal pengoperasian $\mathrm{AC}$, dia akan menyetel pengaturan program, yakni ia menentukan karakteristik dari AC tersebut. Artinya, pembatasan telah ditentukan sedemikian rupa dari awal. Saat mengatur $\mathrm{AC}$, orang tersebut dipengaruhi oleh informasi eksternal (sistem terbuka), seperti misalnya dari lembar petunjuk penggunaan $\mathrm{AC}$ atau dari informasi penghuni rumah yang lain. Segera setelah AC disetel, alat pendingin tersebut akan bereaksi terhadap semua perubahan, yaitu informasi yang diterima oleh sensor otomatis. Alat tersebut mulai mengukur suhu dan kemudian, sebagai tanggapan atau umpan balik, sensor tersebut memberikan sinyal ke mesin pendingin untuk menentukan tinggi-rendahnya suhu ruangan yang selayaknya (diinstruksikan oleh program). Dengan demikian, perubahan suhu ruangan dan reaksi dari AC untuk menyesuaikan dirinya terhadap perubahan tersebut merupakan informasi umpan balik bagi pemilik rumah tersebut yang di kemudian hari 
dapat melakukan perubahan pemrograman alat pendingin ruangannya kembali berdasarkan informasi yang dia terima.

Kita dapat melihat di sini bahwa informasi yang diterima oleh si penghuni rumah (input), dikomunikasikan kembali (output) melalui pengaturan alat pendingin ruangan dan lalu diedarkan melalui sistem yang tertutup yang pada akhirnya kembali orang yang sama sebagai umpan balik. Bahkan jika suhu yang dihasilkan tidak tepat untuk pemilik rumah, ia akan beradaptasi dengan informasi ini atau mengubah dan bereaksi terhadapnya dengan melakukan pengaturan lain sampai ia mendapatkan suhu yang diinginkan. Melalui proses ini, penghuni rumah, pendingin ruangan, dan keseluruhan sistem dapat mempertahankan keseimbangan alur kerjanya. Proses kerja ini lebih tepat digambarkan dengan model komunikasi stimulus-respons atau sebabakibat yang sirkuler (non-linear), yang dengan demikian mengilustrasikan juga prinsip-prinsip umpan balik sibernetis. Dari titik ini kita beranjak pada karakteristik lain dari pendekatan sibernetis, yaitu redundansi sistem, yang akan dijelaskan berikut ini.

Redundansi. Salah satu gagasan yang menjadi dasar perspektif sibernetis adalah bahwa perspektif ini tidak berfokus pada bagian atau isi dari sistem yang tertutup, seperti halnya yang berlaku dalam teori klasik reduksionisme atau sistem stimulus-respons yang linear. Sebaliknya, pendekatan sibernetik melihat sebuah fenomena secara keseluruhan dan berfokus pada pola dan redundansi. Sehubungan dengan hal ini, Bateson mencatat:

The difference between the Newtonian world and the world of communication is simply this: that the Newtonian world ascribes reality to objects and achieves its simplicity by excluding the context of the context-indeed excluding all metarelationships- a fortiori excluding an infinite regress of such relations. In contrast, the theorist of communication insists upon examining the meta-relationships while achieving its simplicity by excluding all objects. (Bateson, 1972).

Menurut Bateson, kelengkapan informasi dalam sebuah proses transmisi pesan tidaklah diperlukan. Ketika berkomunikasi atau mempersepsi pesan/informasi, suatu organisme tidak memerlukan keseluruhan teks (di sini teks didefinisikan secara luas). Alih-alih, Bateson menyoroti pentingnya konteks dalam proses komunikasi (Bateson, 1983). Bateson mencontohkan konsep tersebut seperti berikut ini:

Ketika saya melihat bagian atas dari sebuah pohon yang berdiri tegak, saya dapat memperkirakan - dengan tingkat keberhasilan yang lebih baik daripada hanya sebuah kebetulan - bahwa pohon itu memiliki akar di dalam bumi. Bagian atas objek pohon yang dipersepsi tersebut bersifat redundan (yaitu, berisi 'informasi' tentang), bagian dari sistem 
yang saya tidak dapat saya persepsi karena tidak terlihat (Bateson, 1983).

Bateson melanjutkan, jadi ketika kita mengatakan bahwa sebuah pesan memiliki 'makna' atau berujar 'tentang' sesuatu, maka yang kita maksudkan adalah bahwa ada relevansi yang lebih besar yang terdiri dari pesan-plusreferensi (konteks) dan hal tersebut berarti juga bahwa dunia ini beroperasi berdasarkan prinsip redundansi pesan, pola atau prediktabilitas. (Bateson, 1983).

Namun begitu, ada satu hal substansial yang diperlukan di awal proses komunikasi sebelum kita tahu bahwa ada akar di bawah pohon, yaitu pengalaman. Tentang topik ini kita akan membahasnya pada bagian selanjutnya.

Bateson meyakini bahwa komunikasi adalah tentang pembentukan redundansi atau pola. "Sebuah pola didefinisikan sebagai kumpulan peristiwa atau objek yang memungkinkan pembentukan asumsi sampai batas tertentu ketika keseluruhan wawasan tidak dapat diakses“ (Bateson, 1983). Redundansi membantu untuk memprediksi bagian yang hilang dari serangkaian peristiwa atau informasi yang dikirimkan - seperti misalnya akar pohon. Artinya, bagian-bagian yang hilang ini sama pentingnya tanpa kita harus melihatnya atau mempersepsinya secara langsung.

Pentingnya redundansi pesan tergantung pada setidaknya dua faktor. Yang pertama adalah konteks yang telah disebutkan di atas, atau dalam ungkapan Bateson: "pesan plus lingkungannya“. Hal ini berarti, informasi apapun yang disampaikan harus selalu dikaitkan dengan konteksnya. Selanjutnya, pemahaman seorang aktor komunikasi terhadap konteks sebuah teks tergantung pada faktor yang kedua, yaitu sudut pandang pengamat (Bateson, 1983) dari proses komunikasi ini. Ketika dua orang berkomunikasi, mereka biasanya diamati oleh pihak ketiga. Bahkan jika tidak ada pihak ketiga yang hadir, mereka akan saling mengamati satu sama lainnya dari sudut pandang orang ketiga.

Giesecke telah mengkaji topik ini sejak lama (Giesecke, 2007). Dalam bukunya die Entdeckung der Kommunikativen Welt (The Discovery of the Communicative World), dia menggambarkan bagaimana sudut pandang seorang peneliti sosial dalam perbandingan budaya memengaruhi cara dia mempersepsikan objek investigasinya. Melalui model triadiknya, Giesecke menunjukkan bahwa setidaknya ada tiga sudut pandang berbeda dalam penelitian lintas budaya: "yang akan 'dikenakan" seorang peneliti selama perjalanan penelitiannya adalah budaya sehari-harinya sendiri, budaya asing yang ia amati, dan disiplin ilmu yang ia gunakan dalam penelitiannya“ (Giesecke, 2007). Setiap sudut pandang memiliki budayanya sendiri. Hal ini berarti bahwa modalitas untuk memahami sebuah subjek studi, untuk 


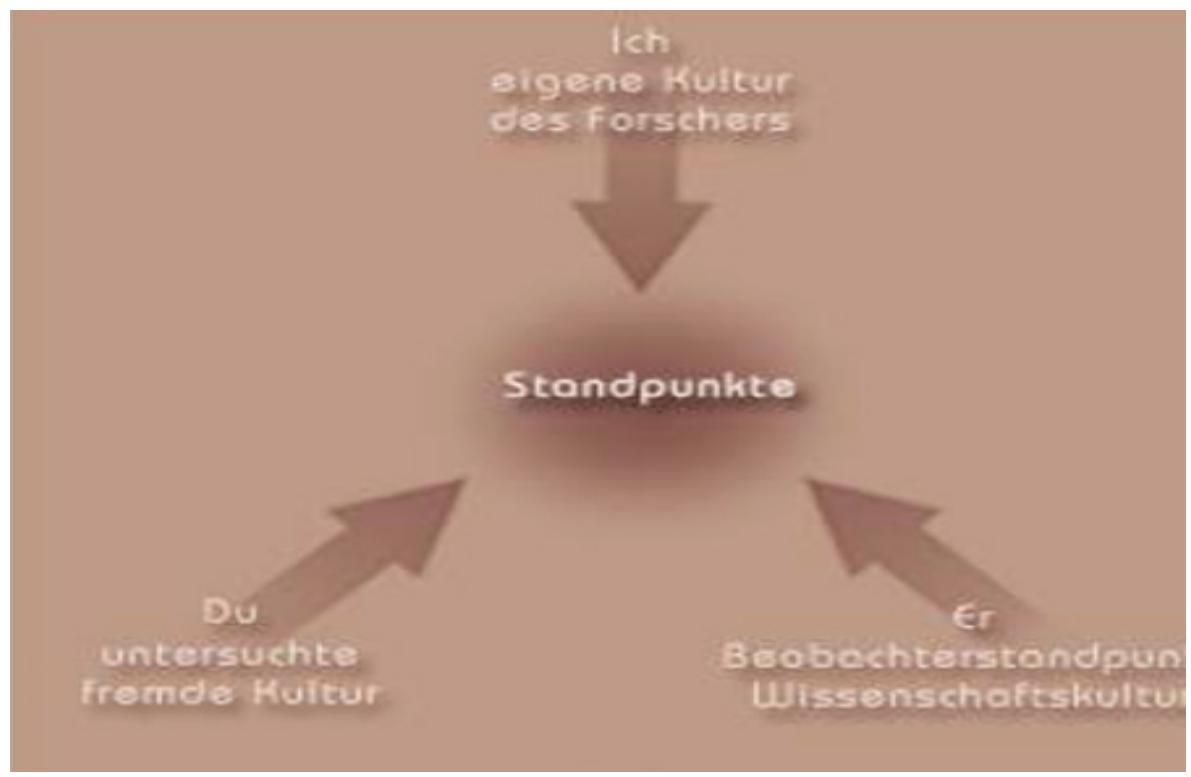

Gambar 1: Sudut pandang peneliti dalam studi komparasi perbandingan budaya

(Sumber gambar: Giesecke dalam http://www.kommunikative-welt.de/entdeckung_web/html/web20 epistemologie kulturvergleichend.htm, diakses 25 April 2008)

membaca konteksnya, atau untuk menebak suatu peristiwa atau redundansi suatu peristiwa, ditentukan juga oleh sudut pandang mana yang dipilih (lihat gambar 1).

Bateson mengklaim bahwa seluruh segala hal di dunia memiliki sifat redundan, di mana prinsip ini merupakan suatu hal yang ikonik dalam komunikasi manusia. Redundansi ini - dalam interaksi antar-manusia - dicapai melalui gerakan isyarat non-verbal, ekspresi wajah, parafrase, atau tindakan-tindakan lainnya, yang memberikan makna pada bagian komunikasi yang hilang (Bateson, 1983). Untuk menegaskan kembali apa yang dimaksud oleh Bateson dari redundansi, pernyataan Bateson berikut ini mungkin dapat membantu: "[...] istilah 'redundansi' [...] sebagian merupakan sinonim untuk 'makna' $[. .$.$] jika penerima pesan$ dapat menyimpulkan bagian pesan yang hilang tersebut [...]“" (Bateson, 1983).

Pendekatan Sibernetis dan Interaksionisme Simbolik. Interaksionisme Simbolik adalah sebuah konsep sosiologi (Mead, 1968). Sebuah definisi dari Burkart berbunyi: "Interaksionisme Simbolik adalah sebuah konsep tentang tindakan manusia, yang terutama berkaitan dengan hubungan manusia dengan lingkungannya, dengan asumsi bahwa manusia tidak hanya hidup dalam lingkungan alamiah, tetapi juga - dan terutama - hidup dalam lingkungan simbolik“ (Burkart, 1998). Burkart melanjutkan, "suatu tanda, yang bertindak sebagai simbol, bukan hanya merepresentasikan sebuah 'objek', tetapi dalam hal ini juga merepresentasikan 
hubungannya dengan objek tersebut. Dengan demikian, tanda selalu melambangkan realitas pengalaman subjektif, yang tidak harus sama untuk setiap orang“ (Burkart, 1998). Pengetahuan, yang dimiliki manusia untuk menafsirkan simbol-simbol disebut "cadangan makna“ (Burkart, 1998) atau - meminjam istilah Schütz - "cadangan pengetahuan" (Schütz, 1993).

Selanjutnya Blumer merumuskan tiga premis penting Interaksionisme Simbolik, yaitu:

Premis pertama mengatakan bahwa manusia bertindak terhadap sebuah 'objek' berdasarkan makna yang dimilikinya untuk objek tersebut. Yang dimaksud dengan 'objek' adalah segala hal dipersepsi oleh manusia dalam dunianya $[\ldots]$

Makna dari objek-objek tersebut berasal dari interaksi sosial yang dilakukan manusia dengan sesamanya, $[\ldots]$

Makna-makna ini dikelola dan dimodifikasi dalam sebuah proses interpretatif yang dilakukan oleh manusia dalam berurusan dengan segala hal (objek-objek) yang ditemuinya [...]. (Blumer, 1973).

Dengan demikian jelaslah bahwa untuk menghasilkan komunikasi yang efektif dan untuk mencapai pemahaman bersama di antara para aktor komunikasi maka, "komunikasi antar-manusia mensyaratkan $[. .$.$] cadangan$ tanda-tanda yang melambangkan $[\ldots]$ objek- objek yang sama untuk para aktor komunikasi yang terlibat" (Burkart, 1998). Selanjutnya, sebuah simbol, yang ditafsirkan oleh manusia dalam suatu proses komunikasi, sehingga simbol tersebut memiliki makna untuk setiap aktor komunikasi, disebut Mead sebagai "simbol signifikan". "Sebuah simbol signifikan adalah sebuah tanda yang mengekspresikan ide yang mendasarinya (memiliki konten ide tertentu) dan simbol ini juga memicu persepsi ide (yang sama) pada lawan komunikasi [...].“ (Burkart, 1998; Mead, 1968).

Dalam komunikasi, interaksi antarpeserta merupakan aspek yang penting sehingga cadangan makna dari orang-orang yang terlibat dalam proses komunikasi tersebut selalu diperbarui, yang kemudian memperkaya pengetahuan manusia. Kita memerlukan pengetahuan yang diperbarui ini untuk menafsirkan beragam objek yang berbeda dengan "benar". Kemampuan ini penting terutama dalam konteks komunikasi antar-budaya sehingga kesalahpahaman dapat dihindari.

Burkart (Burkart, 1998) menjelaskan konsep ini melalui sebuah model situasi komunikasi antar-manusia:

Model pada gambar 2 menunjukkan bagaimanakesepahamanmunculdiantara orangorang yang terlibat dalam situasi komunikasi tertentu (artinya tergantung konteks). Seperti 


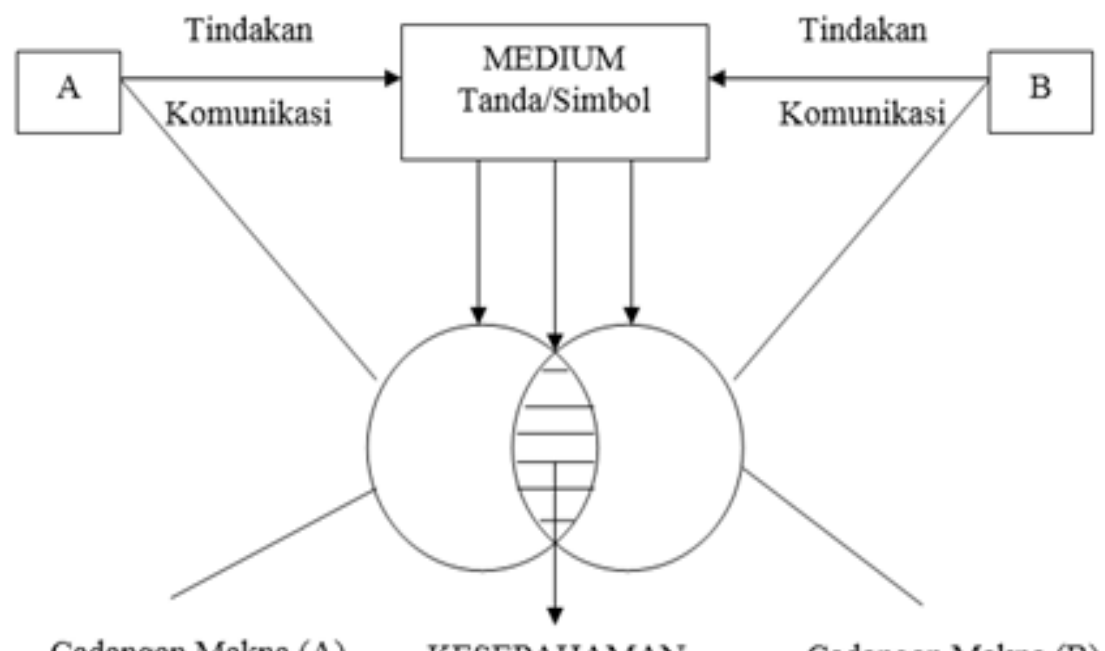

Cadangan Makna (A) KESEPAHAMAN

Cadangan Makna (B)

Gambar 2: Ilustrasi dari sebuah situasi komunikasi antar-manusia

Sumber : (Burkart, 1998)

yang telah disinggug di atas, untuk mencapai kesepahaman antara dua peserta komunikasi (A dan B), maka diperlukan cadangan makna/ pengetahuan yang sama dari A dan B. Dalam model seperti yang ditampilkan dalam Gambar 2, kesamaan cadangan makna/pengetahuan ini ditunjukkan oleh irisan yang berada di tengahtengah gambar. Semakin kecil irisan ini, maka semakin besar pula peluang untuk terjadinya kesalahpahaman di antara orang-orang yang terlibat dalam proses komunikasi tersebut. Interaksionisme Simbolik merupakan salah satu konsep dasar untuk memahami proses komunikasi manusia. Konsep ini menunjukkan bagaimana manusia berkomunikasi satu sama lain dan memroses informasi.

'Konteks' memainkan peranan yang penting dalam komunikasi manusia. Mari kita bayangkan situasi komunikasi berikut ini: Seorang warga asing yang, walaupun bisa berbicara bahasa Indonesia dengan baik, mungkinmenganggapbahwa kalimat "kejatuhan durian runtuh" merujuk pada suatu situasi yang tidak menyenangkan atau sebuah kondisi yang malang dari seseorang karena tertimpa musibah (durian runtuh). Ia mungkin memahami kalimat tersebut secara harfiah. Namun, kalimat tersebut sesungguhnya merupakan sebuah ungkapan yang justru merujuk pada situasi dimana seseorang mengalami kebahagiaan atau mendapatkan keberuntungan yang tidak diduga. Di sini kita melihat kesalahpahaman antara lawan bicara, karena salah seorang peserta komunikasi tidak memiliki "cadangan pengetahuan“ tentang konteks ekspresi dalam Bahasa Indonesia. Tidak ada kesepahaman di antara para peserta komunikasi tersebut, oleh karena itu, tidak ada komunikasi, seperti yang 
dinyatakan oleh Bateson sehubungan dengan pendekatan sibernetis berikut ini: “[...] sebuah kata memiliki eksistensi - memiliki 'makna' hanya dalam konteks ucapan yang lebih luas, yang juga memiliki makna hanya dalam suatu relasi tertentu [...]. Dalam sibernetis (berlaku formula): Tanpa konteks, tiada komunikasi“ (Bateson, 1983).

Dalam bab sebelumnya telah dibahas mengenai redundansi, yaitu diperlukan pengalaman untuk mengetahui bahwa ada akar di bawah sebuah pohon yang berdiri tegak. Dalam Interaksionisme Simbolik, hal tersebut berarti "cadangan pengetahuan". Maksudnya, kita perlu setidaknya mempersepsi satu kali, apakah dengan membaca buku, menonton televisi, berkomunikasi dengan orang lain, atau melalui pengamatan sendiri secara langsung, dengan kata lain, kita perlu berinteraksi dengan organisme lain atau dengan objek yang dikonstruksi secara sosial, bahwa di bawah pohon terdapat akar. Melalui proses ini, pengetahuan kita tentang "relasi pohon-akar" telah diaktualisasi. Karena basis pengetahuan kita telah ditambahkan dengan informasi tentang pohon dan akar, maka tidak sulit bagi kita untuk menentukan bagian yang hilang dari teks "pohon - tegak - bumi" adalah "akar". Oleh karena itu kita dapat mengatakan bahwa redundansi membutuhkan pengalaman.

Seperti halnya dalam pendekatan sibernetis, dalam Interaksionisme Simbolik juga belaku formula stimulus-(organisme)-respon. Kami sekarang mengetahui bahwa aktualisasi pengetahuan memerlukan interaksi sosial. Dalam interaksi sosial, terdapat pertukaran informasi, sinyal atau umpan balik, dalam arti bahwa kita memberikan sinyal kepada orang lain (output), dimana orang tersebut mempersepsi sinyal itu (input) atau sinyal tersebut dapat juga dapat dianggap sebagai input oleh kita sendiri secara langsung, jika kita berefleksi terhadap sinyal yang kita sampaikan. Informasi ini merangsang organisme lain yang mempersepsi informasi kita. Informasi tersebut lalu diproses (throughput) dan dikembalikan pada kita sebagai umpan balik (output) yang kembali kita persepsi (input). Dari sini, proses yang sama kembali berulang. Mengenai hal ini, Bale merumuskan pandangannya sebagai berikut:

In an organism, sensory signals, such as the pain which results from touching a hot object, constitute feedback. In social relations, feedback reports the result-or the perceived result--of our behavior on other persons, such as our perception of a smile or frown in return for our own [...] Particularly in relation to the selfstabilizing and self-organizing nature of a system (i.e., cybernetic stability), the mutual causal effects of feedback have been recognized as invaluable tools for appropriately explaining the interaction observed in the relationship of a system with its environment (Bale, 1995).

Pada prinsipnya, komunikasi bekerja di 
dalam semua sistem yang mengatur dirinya sendiri (self-regulating system) dengan cara seperti ini dan dengan cara yang sama pula, sistem-sistem semacam ini mempertahankan keseimbangannya.

Pendekatan Sibernetis dan Fenomenologi

Salah satu pertanyaan yang substansial dari pendekatan fenomenologi sosial Alfred Schütz adalah: "Bagaimana ego dan alter dapat berkomunikasi dengan satu sama lain, jika mereka tidak berbagi makna yang sama?“ (Schützeichel, 2004). Menurut Bateson, jawabannya terlatak pada redundansi, dalam arti bahwa seseorang menutup kesenjangan antara ego dan usia dengan memperhatikan seluruh pola tindakan. Tentang hal tersebut Mead menekankan apa yang disebutnya simbol signifikan dan menyatakan bahwa simbolsimbol ini dicapai melalui interaksi sosial secara bertahap. Pada titik ini, konteks dari masingmasing tindakan komunikatif merupakan suatu hal yang fundamental. Sehubungan dengan konsep pola, Schütz memperkenalkan apa yang kemudian dimaknai sebagai tipifikasi.

Menurut Schütz, dalam pertemuan dengan orang lain kita tidak mungkin memahami makna subyektif yang dimaksud oleh orang tersebut makna tersebut tidak dapat dimengerti dan dalam beberapa hal tidak dapat dikomunikasikan. Namun, kita dapat memahami makna tipikal (khas) dari hal yang dimaksud oleh orang tersebut. Kita bertemu dengan orang lain, diri kita sendiri dan semua objek dari pengalaman kita hanya dalam bentuk tipikalnya. Tipifikasi dapat diartikan sebagai skema interpretasi. (Schützeichel, 2004).

Tergantung dari masing-masing situasi, konteks atau - dengan meminjam istilah Schütz - "relevansi masalah"-nya, ada tiga bentuk tipifikasi atau pola, yaitu:

(1) Tipe individu didasari oleh kenyataan bahwa seseorang melakukan tindakan dan kita membentuk harapan yang spesifik terhadapnya yang hanya menjadi karakteristik bagi orang tersebut sebagai pribadi. (2) Tipe peran, di sisi lain, dibangun dari bentuk-bentuk tindakan dan ekspektasi yang khas dari anggota-anggota kelompok orang dengan kategori tertentu. Dan (3) tipe umum dari suatu urutan tindakan ditemukan dalam bentuk-bentuk tindakan dan harapan dalam situasi yang spesifik yang tidak terbatas pada orang atau peran (Schützeichel, 2004).

Hubert Knoblauch dan Thomas Luckmann menawarkan konsep yang serupa dan menyebutnya dengan konsep genre komunikatif (communicative genres) (Knoblauch \& Luckmann, 2000). "Luckmann mendefinisikan genre komunikatif sebagai proses kompleks yang telah ditentukan secara sosial ('pola') yang telah mencapai tingkat keterikatan tertentu dan yang dapat dipahami sebagai sedimentasi 
khusus yang menyejarah dan membudaya untuk solusi permasalahan sosial“" (Auer, 1999, pp. 177-178). Dengan demikian, redundansi, pola, tipifikasi, dan genre kurang lebih merupakan konsep yang serupa, yang menjadi orientasi kita dalam memahami orang lain atau partner komunikasi kita.

Seperti yang disebutkan dia atas, struktur proses komunikatif dalam suatu sistem ditentukan oleh interaksi antar-organisme. Struktur ini ditentukan dan dilembagakan di dalam masyarakat, sebagai sebuah sistem besar yang terdiri dari banyak sub-sistem interaktif yang lebih kecil. Melalui sistem komunikasi seperti ini, biasanya kita tidak menemukan masalah dalam memahami, bahwa ada akar di bawah sebuah pohon yang berdiri tegak, bahwa orang bertepuk tangan setelah sebuah penampilan yang mengesankan, bahwa orang bersalaman di hari raya, bahwa orang melambaikan tangan dalam momen perpisahan, atau orang saling menyapa di jalan (biasanya di komunitas perdesaan), terlepas dari apakah mereka mengenal satu sama lain atau tidak. Hal ini karena menurut pendekatan sibernetis, akar di bawah pohon, tepuk tangan setelah pertunjukan, salaman di hari raya, lambaian tangan pada saat perpisahan, dan sapaan pada orang lain memiliki kemungkinan yang lebih besaruntuk berlaku sebagai peristiwa atau bagian dari rangkaian peristiwa dalam konteks yang khusus, karena hal-hal tersebut sesuai dengan lingkungan/sistem/konteks komunikasinya dan sesuai dengan prinsip pembatasan dan 'seleksi alam

Pohon yang berdiri tegak juga bisa dipahami sebagai tanda untuk akar atau objekobjek lainnya yang termasuk ke dalam sistem 'pohon plus lingkungannya', seperti misalnya cuaca atau air. Terkait dengan hal tersebut, “Schütz [...] merujuk pada konsep Husserl, yaitu appresentasi (appresentation). Appresentasi dapat diterjemahkan sebagai ko-visualisasi (Mitvergegenwärtigung dalam bahasa Jerman) [...] yang merupakan hubungan antara sesuatu yang keberadaannya jelas bagi seseorang, yang merujuk pada sesuatu yang tidak ada (dan) membangkitkan atau memanggil (ke dalam kesadaran, sesuatu yang tidak ada tersebut)“ (Schützeichel, 2004). Misalnya, jika kita mempersepsi sebuah pohon di taman-agar tetap berada dalam topik yang sama -, maka persepsi kita terhubung ke banyak kemungkinan/harapan yang berbeda, dengan kata lain, terhubungan dengan bagian-bagian yang hilang dari sistem pohon plus kebun (lingkungannya). Kita dapat dengan yakin memvisualisasikan bagian yang hilang ini, yang juga merupakan bagian dari sistem tersebut, misalnya (tergantung konteks), akar, tukang kebun, hewan, atau air, walaupun kita tidak melihatnya secara langsung pada saat itu. Ini artinya, “dalam persepsi kita, selalu ada 
pasangan (objek-objek), yaitu sisi objek yang ditampilkan dan sisi objek yang divisualisasikan (berdasarkan objek yang ditampilkan tersebut)“ (Schützeichel, 2004). Menurut Bateson segala hal di dunia ini mengikuti prinsip redundansi, oleh karenanya kita dapat berasumsi bahwa prinsip appresentasi juga berlaku. Dengan pemaparan ini, kita melihat adanya hubungan di antara pendekatan sibernetis dan pendekatan fenomenologis dalam konteks komunikasi.

Lebih jauh, jika kita membahas karyakarya Schütz, kita tidak boleh melewatkan tesis lain darinya, yaitu the general thesis of the reciprocity of perspectives (tesis umum tentang resiprosikal perspektif).

The general thesis of the reciprocity of perspectives menempati posisi yang sangat penting dalam teori sosial Schütz. Tesis ini memastikan kohesi sosial dan bersifat konstitutif untuk tatanan sosial. Tesis ini juga mengatur komunikasi sedemikian rupa sehingga perbedaan perspektif yang sangat jelas antarmanusia dinetralisasi sampai kemudian ada pemberitahuan lanjutan. (Schützeichel, 2004).

Di satu sisi, tesis ini berkenaan dengan idealisasi kesesuaian sistem relevansi (idealization of the conformity of relevance systems). Idealisasi ini berarti bahwa manusia memiliki pengalaman yang berbeda dan dalam beberapa hal tidak memiliki pengetahuan yang sama. Pada titik ini kita dapat mengingat kembali konsep Interaksionisme Simbolik, di mana di dalamnya dijelaskan bagaimana interaksi sosial memainkan peranan yang penting dalam mewujudkan saling pengertian atau kesepahaman. Dari sini, kita menuju pada aspek kedua dari resiprositas, yaitu idealisasi pertukaran sudut pandang (idealization of interchangeability of viewpoints). Idealisasi ini mengartikan bahwa "dalam komunikasi [...] kita (menganggap) orang lain, jika mereka menempati titik pijak saya, akan melihat hal-hal sebagaimana saya memandang hal-hal tersebut" (Schützeichel, 2004).

Sebuah sistem yang tertutup juga dikatakan memiliki resiprositas. Saat terjadi interaksi antar-komponen dalam sistem, maka diharapkan akan terjadi pertukaran informasi/energi. Jika ada salah satu komponen sistem yang memicu pengeluaran informasi/energi, maka informasi/ energi tersebut akan memengaruhi bagian lain dari sistem tersebut dan menyampaikan informasi/energi kembali (umpan balik) kepada komponen sistem yang mengeluarkan informasi/energi awal. Hal ini sesuai dengan prinsip idealisasi pertukaran sudut pandang, yaitu bahwa setiap komponen yang menerima rangsangan (input) akan memicu pengeluaran (output) informasi/energi (yang telah diproses/diubah/throughput) sebagai respon atas diterimanya informasi/energi tersebut. Bale dengan merujuk pada Bateson (1965), 
menjelaskan sifat-sifat resiprositas sistem sebagai berikut:

Feedback 'mechanisms' are circular and self-referential by nature. In the closed circuitry" of a feedback loop, "cause" and "effect" cannot be categorically isolated. They modify each other in a continuous process where input and output, percepts and performance, interact. This complex interaction between perception and action, evident in exploratory and learning behaviors, is the means by which a system-animal or machine--has the capacity to adapt, organize and increase its complexity. It is the key to a system's self-organization and its self-stabilization. Thus, cybernetic models mandate explanation in terms of serial and reciprocal sequences of cause and effect (Bale, 1995).

Penjelasan di atas memaparkan fakta bahwa sistem-sistem di dunia ini menerapkan prinsip resiprositas. Dengan cara ini sistem-sistem tersebut mempertahankan keseimbangan aliran kerja mereka, bertahan dalam seleksi alam dan mempertahankan hidup mereka.

Pendekatan Sibernetis dan Teori Kekacauan

\section{(Chaos Theory)}

"Kepakan sayap kupu-kupu di hutan Amazon dapat memicu badai di Amerika." Idiom umum semacam itu merupakan efek kupu-kupu atau butterfly effect dan seringkali dijadikan ilustrasi dalam penjelasan mengenai teori kekacauan atau chaos theory. Sebagai istilah ilmiah, kata "chaos" pertama kali digunakan dalam matematika. Pada awal abad kedelapanbelas, ahli matematika Prancis Pierre-Simon Laplace memproklamirkan prediktabilitas berjalannya segala sesuatu, dengan syarat bahwa kondisi awal atau pembatasannya diketahui. Dia mengklaim:

Kondisi dari sistem alam saat ini jelas merupakan konsekuensi dari apa yang terjadi pada (sistem tersebut) saat sebelumnya, dan jika kita membayangkan sebuah kecerdasan yang dapat memroses semua hubungan di antara bagian-bagian alam semesta pada waktu tertentu, maka kecerdasan tersebut bisa memprediksi tempat, pergerakan, dan hubungan umum di antara semua bagian itu untuk semua momen di masa lalu dan masa depan (Loistl \& Betz, 1996).

Hal ini menunjukkan bahwa semua bagian dari alam semesta saling terhubung. Mereka saling mempengaruhi dan berhubungan satu sama lain. Perubahan kecil dalam kondisi awal bisa berdampak besar pada keseluruhan sistem. Ini menimpa semua variabel dalam sistem yang besar ini yang menerima rangsangan dan mengeluarkan reaksi atau umpan baliknya ke variabel yang lain. Para ilmuwan menyebut keadaan ini sebagai 'kekacauan deterministik' (Loistl \& Betz, 1996). Sehubungan dengan hal tersebut, Edward Lorenz, seorang meteorolog Amerika dari Massachusetts Institute of Technology (MIT) menggambarkan perilaku ini pada tahun 1963 dengan mengonsep sebuah model iklim matematis. Model ini, yang kini dikenal sebagai 'efek kupu-kupu' (the butterfly 
effect), menggambarkan "bahwa pergerakan udara yang disebabkan oleh hentakan sayap kupu-kupu dalam rentang molekuler dapat meningkatkan dan mengembangkan badai di Amerika melalui umpan balik nonlinear. Penyebab kecil yang 'tak terhingga', yang diabaikan oleh para pengamat dapat menyebabkan perubahan perilaku sistem yang 'ketat' secara keseluruhan yang tampaknya tidak dapat dijelaskan“ (Loistl \& Betz, 1996; Rath, n.d.).

'Nonlinieritas' (non-linearity) dan 'penyambungan' (coupling) adalah dua karakteristik penting dari sistem semacam itu sehingga sistem dapat mempertahankan eksistensi dan keteraturannya yang kompleks. Sifat-sifat tersebut berlaku untuk semua sistem kehidupan di alam semesta, termasuk dalam masyarakat modern kita dan manusia di dalamnya. Teori kekacauan, seperti halnya juga teori sistem umum dari Bertalanffy, memberikan perhatian lebih besar pada keseluruhan sistem. "Keseluruhan sistem lebih (bernilai) dari pada jumlah seluruh bagian-bagiannya“ (Loistl \& Betz, 1996). Selain dari itu, Gerok membedakan sistem kehidupan seperti di atas dari model linear reduksionis dalam empat aspek:

Ia memiliki tingkat kerumitan yang tinggi melalui jaringan proses dan rantai sebab akibat.

Ia adalah sistem terbuka yang-berbeda dengan subproses yang terisolasi secara artifisial-terus menyerap dan melepaskan materi, energi, dan informasi.

Reaksi yang terjadi dalam sistem kehidupan biasanya tidak berada dalam, tetapi jauh dari keseimbangan. Banyak reaksi juga tidak dapat diubah (irreversible).

Putaran reaksi merupakan aturan dalam sistem kehidupan ... Kinetika reaksi semacam itu tidak dapat dijelaskan dengan persamaan diferensial linear (Gerok, 1989).

Keempat aspek ini juga dapat ditemukan dalam pendekatan sibernetis. Aspek-aspek ini menjelaskan bagaimana manusia, sebagai sistem yang kompleks, menemukan cara untuk bertahan hidup. Sebagaimana telah dijelaskan oleh prinsip penjelasan negatif, Scheidegger juga berpendapat bahwa "manusia dan rohnya [...] tidak (berada) di luar 'alam' [...], melainkan (mereka adalah) hasil dari evolusi alamiah“ (Scheidegger, 1997).

\section{SIMPULAN}

Pendekatan sibernetis menawarkan perspektif yang berbeda untuk menjelaskan suatu fenomena. Perspektif ini memiliki sifat-sifat ilmu alam (seperti teori sistemnya Bertalanffy) yang diimplementasikan untuk menjelaskan fenomena komunikasi, khususnya untuk menjelaskan bagaimana kesepahaan antarmanusia dimungkinkan. Pendekatan sibernetis menyatakan antara lain bahwa elemen-elemen 
dari suatu sistem saling berhubungan dan berinteraksi, dan bahwa sistem-sistem tersebut tertutup dan terbuka. Sistem tersebut tertutup dalam arti bahwa informasi, energi atau materi yang melewati sistem diumpankan kembali ke titik awal. Namun ia juga terbuka karena sistem seperti itu memungkinkan semua rangsangan dari luar masuk ke dalam sistem yang akan membawa perubahan pada keseluruhan sistem.

Prediktabilitas dikaitkan dengan sistem sibernetis, baik itu organisme seperti manusia, masyarakat atau ekosistem yang lebih besar. Dengan ini dimaksudkan bahwa sistem seperti itu memiliki struktur dan pola yang teratur, dan jika kita mengetahui karakteristik dari masing-masing sisitem dan mengaitkannya dengan lingkungan dan konteksnya, kita mungkin tahu apa yang akan terjadi dalam sebuah rangkaian peristiwa. Bateson menyebut karakteristik seperti itu redundansi. Selain itu, pendekatan sibernetis memiliki kesesuaian dengan teori evolusi atau seleksi alam. Sejalan dengan hal tersebut, prinsip penjelasan negatif memaparkan bagaimana suatu peristiwa terjadi dan bagaimana suatu organisme dapat bertahan hidup dengan beroreintasi pada faktor-faktor yang membantunya beradaptasi dengan lingkungannya (yang berubah). Di sini Bateson berbicara tentang pembatasan.

Pendekatan sibernetis dapat juga diturunkan dari paradigma komunikasi fenomenologis, seperti dari Alfred Schütz dan Thomas Luckmann karena artikel ini berfokus pada pada aspek komunikasi. Dalam paradigma ini, konteks dalam komunikasi memiliki posisi yang penting. Juga tidak boleh diabaikan bahwa resiprositas memainkan peranan yang signifikan untuk memastikan bahwa suatu sistem dapat mempertahankan keseimbangannya atau, dalam istilah komunikasi interpersonal, berkomunikasi dan memahami satu sama lain. Resiprositas mensyaratkan adanya interaksi.

Pada titik inilah terletak pertemuan antara pendekatan sibernetis dengan interaksionisme simbolik. Akhirnya, prinsip-prinsip sibernetika dapat ditemukan dalam salah satu teori yang dikenal dalam matematika, yaitu teori kekacauan atau chaos theory. Istilah seperti prediktabilitas, sistem yang nonlinier atau umpan balik juga digunakan dalam teori kekacauan untuk memberikan penjelasan bagaimana suatu peristiwa terjadi.

\section{DAFTAR PUSTAKA}

Auer, P. (1999). Prachliche interaktion: eine einführung anhand von 22 klassikern. Tübingen: Niemeyer.

Bale, L. S. (1995). Gregory Bateson, cybernetics and the social/behavioral science. Cybernetics \& Human Knowing: A Journal of Second Order Cybernetics \& Cyber-Semiotics, 3(1), 27-45.

Bateson, G. (1965). Naven. Stanford: Stanford University Press. 
Bateson, G. (1972). Steps to an ecology of mind. San Francisco: Chandler.

Bateson, G. (1983). Ökologie des geistes: anthropologische, psychologische, biologische und epistemologische perspektiven (6th ed.). Frankfurt am Main: Suhrkamp Verlag.

Bateson, G. (1984). Geist und natur: eine notwendige einheit. Frankfurt am Main: Suhrkamp Verlag.

Bertalanffy, L. (1998). General system theory (12th ed.). New York: George Braziller.

Blumer, H. (1973). Der methodologische standortdes symbolischeninteraktionismus. In Arbeitsgruppe Bielefelder Soziologen: Alltagswissen, Interaktion und gesellschaftliche Wirklichkeit (1st ed., pp. 80-146). Reinbek bei Hamburg: Rowohlt Taschenbuch Verlag.

Burkart, $\mathrm{R}$.

(1998). Kommunikationswissenschaft: grundlagen und problemfelder. Umrisse einer interdisziplinären Sozialwissenschaft (3rd ed.). Wien: Böhlau Verlag.

Gerok, W. (1989). Ordnung und chaos in der unbelebten und belebten natur. Stuttgart: S. Hirzel.

Giesecke, M. (2007). Die entdeckung der kommunikativen welt (Studien zu). Frankfurt am Main: Suhrkamp Verlag.

Knoblauch, H., \& Luckmann, T. (2000). Gattungsanalyse. In U. Flick (Ed.), Qualitative Forschung (pp. 538546). Reinbek bei Hamburg: Rowohlt Taschenbuch Verlag.

Laszlo, E. (1973). Introduction to systems philosophy. New York: Harper Torchbook.
Loistl, O., \& Betz, I. (1996). Chaostheorie: zur theorie nichtlinearer dynamischer systeme (3rd ed.). München \& Wien: R. Oldenbourg Verlag.

Mead, G.H.(1968). Geist, identität, gesellschaft: aus der sicht des sozialbehaviorismus (C. W. Morris, Ed.). Frankfurt am Main: Suhrkamp Verlag.

Mirawati, I., \& Karimah, K. El. (2018). Chinese harmony communication theory: kompetensi komunikasi untuk keseimbangan hidup. Jurnal Manajemen Komunikasi, 3(1), 97-121.

Putri, N. E., Hakim, N., \& Yamin, M. (2016). Ecologicall footprint and biocapacity analysis for flooding prevention in South Sumatera. Jurnal Mimbar, 32(1), 58-64.

Rath, G. (n.d.). Vom chaos zur chaostheorie.

Scheidegger, A. E. (1997). Heilige Kühe: Chaos-Theorie der Human-Evolution. Frankfurt am Main: Peter Lang.

Schütz, A. (1993). Der sinnhafte aufbau der sozialen welt: eine einleitung in die verstehende sozilogie (6th ed.). Frankfurt am Main: Suhrkamp-Taschenbuch Wissenschaft.

Schützeichel, R. (2004). Soziologische kommunikationstheorien. Konstanz: UVK Verlagsgesellschaft $\mathrm{mbH}$.

Shannon, C. E., \& Weaver, W. (1964). The mathematical theory of communication (6th ed.). Urbana: University of Illinois Press.

Wiener, N. (1948). Cybernetics: or control and communication in the animal and the machine (2nd ed.). Cambridge, Massachusetts: MIT Press. 